\title{
MANAJEMEN SDM ISLAMI DALAM MENINGKATKAN KINERJA KARYAWAN DI CV ADEEVA GROUP JEMBER
}

\author{
Ach. Fadlail dan Fatimala \\ Ach.fadlail@gmail.com dan Fatimala007@gmail.com \\ Fakultas Syariah dan Ekonomi Islam Universitas Ibrahimy Situbondo
}

\begin{abstract}
ABSTRAK
CV Adeeva Group Besuk Wirowongso Jember menerapakan manajemen SDM yang berbasis Islam pada perusahannya. Manajemen SDM Islami yang diterapkan memiliki dampak positif bagi etos kerja karyawan. Strategi manajemen SDM Islami adalah semua kegiatan yang mengatur sumber daya manusia dan bertujuan untuk beribadah kepada Allah. Kinerja karyawan adalah suatu proses yang dirancang untuk meningkatkan kinerja organisasi, kelompok dan individu yang digerakkan oleh para manajer. Tujuan dari penelitian ini untuk mengetahui strategi manajemen sumber daya manusia Islaminya dalam meningkatkan kinerja karyawan di CV Adeeva Group Besuk Wirowongso Jember. Hasil kajian ini menunjukkan bahwa strategi manajemen sumber daya manusia Islami yang ada di CV Adeeva Group Besuk Wirowongso Jember menerapakan adanya keadilan, pelatihan dan pengembangan, konpensasi serta disiplin kerja.
\end{abstract}

Kata Kunci: MSDM Islami dan Kinerja Karyawan

\section{PENDAHULUAN}

Indonesia merupakan salah satu Negara yang dikaruniai SDM yang melimpah dan harus dikelola dengan baik sehingga bisa menghasilkan input yang bermanfaat. Dalam pengelolaan SDA bisa memberikan manfaat yang sangat signifikan bagi masyarakat. Islam juga memberikan perhatian yang sangat tinggi terhadap sumber daya manusia. Karena Islam diturunkan ke muka bumi untuk memperbaiki manusia, Islam juga memandang penting pembangunan, karena dalam pembangunan, tersebut sumber daya manusia merupakan kunci yang paling menentukan keberhasilan pembangunan. ${ }^{1}$ Manusia merupakan perencana, pelaku, serta pengaktualisasi pembangunan. Oleh karena itu, pengembangan kualitas sumber daya manusia merupakan kunci utama dalam pembangunan melalui kualitas sumber daya manusia yang unggul, maka manusia mampu hidup bertahan dan berkembang sepanjang zaman seiring denagan perubahan.

\footnotetext{
${ }^{1}$ Buchari Alma dan Doni, Manajemen Bisnis Syari'ah (Bandung: Penerbit Alfabeta, 2014), 307.
} 
Strategi pengembangan sumber daya manusia Islami yang dilakukan oleh Nabi Muhammad SAW yaitu merencanakan dan menarik sumber daya manusia yang berkualitas. ${ }^{2}$ Mengembangkan sumber daya manusia agar berkualitas, menilai kinerja sumber daya manusia, memberikan motivasi dan memelihara sumber daya manusia yang berkualitas. Karena perencana sumber daya manusia Islami yang dilakukan Nabi Muhammad SAW mengacu pada al-Qur'an untuk menjadikan orang berlaku adil, berbuat kebajikan, memberi bantuan, melarang kemungkaran, kekejian dan permusuhan. Seperti firman Allah SWT yang artinya: "Sesungguhnya Allah menyuruh (kamu) berlaku adil dan berbuat kebajikan, memberi kepada kaum kerabat, dan Allah melarang dari perbuatan keji, kemungkaran dan permusuhan. Dia memberi pengajaran kepadamu agar kamu mengambil pelajaran”. (Q.S. AnNahl ayat: 90$)^{34}$

Ayat tersebut, Allah SWT memerintahkan berbuat adil dalam melaksanakan isi al-Qur'an yang menjelaskan segala aspek kehidupan manusia, serta berbuat ihsan (keutamaan) adil berarti mewujudkan kesamaan dan keseimbangan diantara hak dan kewajiban mereka. Manusia merupakan sumber daya manusia paling penting dalam usaha organisasi untuk mencapai keberhasilan. Sumber daya manusia ini menunjang organisasi dengan karya, bakat, kreatifitas dan dorongan. ${ }^{5}$ Betapapun sempurnanya aspek teknologi dan ekonomi, tanpa aspek manusia sulit tujuan-tujuan organisasi dapat dicapai. Manusia salah satu unsur produksi merupakan faktor paling penting dan utama didalam segala bentuk organisasi. Faktor penting disini sifatnya komplek sehingga perlu mendapatkan perhatian, penanganan, dan perlakuan khusus disamping faktor produksi yang lain.

Karyawan adalah orang menjual jasa (pikiran dan tenaganya) dan mendapatkan kompensasi yang besarnya telah ditetapkan terlebih dahulu. Mereka wajib dan terikat untuk mengerjakan pekerjaan yang diberikan dan berhak

${ }^{2}$ Veithzal Rivai. Dam Muhammad Syafii Antonio Dkk, Islamic Business Management (Yogyakarta: BPF cet. ke-2, 2017), 327. 4.

${ }^{3}$ Departemen Agama RI, AL-Qur'an dan Terjemahanya (Semarang: Karya utama, 2008),

${ }^{5}$ Toto Tasmara, Etos Kerja Pribadi Mulia (Yogyakarta: PT Dana Bhati Wakaf 1995), 2. 
memperoleh konpensasi sesuai dengan perjanjian. ${ }^{6}$ Kinerja karyawan merupakan hal yang bersifat individual, karena setiap karyawan mempunyai tingkat kemampuan yang berbeda-beda dalam mengerjakan tugasnya. Istilah kinerja berasal dari kata job performance atau actual performance yang berarti prestasi atau prestasi yang sesungguhnya yang dicapai oleh seseorang. ${ }^{7}$ Kinerja tergantung pada kombinasi antara kemampuan, usaha dan kesempatan yang diperoleh. Hal ini berarti bahwa kinerja merupakan hasil kerja karyawan dalam bekerja untuk waktu tertentu dan penekanannya pada hasil kerja yang diselesaikan karyawan dalam waktu tertentu.

Kepuasan kerja (job satistfaction) adalah tingkat saat karyawan memiliki perasaan positif terhadap pekerjaan yang ditawarkan perusahaan tepatnya bekerja. ${ }^{8}$ Kepuasan kerja merupakan salah satu elemen yang cukup penting dalam organisasi. Dorongan utama seorang Muslim dalam bekerja adalah bahwa aktivitas kerjanya itu dalam pandangan Islam merupakan dari ibadah. Selain dorongan ibadah, seorang muslim juga dapat bekerja keras karena adanya keinginan untuk dapat memperoleh imbalan atau penghargaan material dan non material. Seperti gaji atau penghasilan, karir dan kedudukan yang lebih baik. Dengan seperti ini sadarlah bahwa setiap muslim tidaklah akan bekerja hanya sekedar untuk mendapatkan gaji, dapat surat pengangkatan atau sekedar menjaga gengsi supaya tidak disebut sebagai pengangguran, karena kesadaran bekerja produktif serta dilandasi semangat tauhid merupakan salah satu ciri yang khas dari karakter atau pribadi seorang muslim. ${ }^{8}$

CV. Adeeva Group merupakan sebuah perusahaan yang didirikan oleh Ibu Ana Mahnan pada tahun 2017. CV. Adeeva Group merupakan bidang usaha yang bergerak dibidang produksi camilan yang memiliki peran besar dalam mengelola sumber daya manusia secara Islami sehingga dapat memiliki keunggulan dan mampu bersaing dengan perusahaan lainnya. Dengan adanya IT yang semakin hari semakin canggih, maka semakin mampu membuat perusahaan ini dalam menambah

\footnotetext{
${ }^{6}$ Malayu SP Hasibun, Manajemen Sumber Daya Manusia Dasar dan Kunci Keberhasilan (Jakarta: Haji Masagung, 1994), 13.

${ }^{7}$ Muhammad Imail Yusanto dan Muhammad Charabet Widjajakusuma, Menggaagas Bisnis Islam (Jakarta: Gema Insani, 2002), 199.

${ }^{8}$ Istijanto, Riset Sumber Daya Manusia (Jakarta: PT Gramedia Pustaka Utama, 2005), 181.

${ }^{8}$ Toto Tasmara, Etos Kerja Pribadi Mulia, 4.
} 
keunggulannya, baik dari segi SDM produksi, distribusi dan promosi hingga saat ini. CV. Adeeva Group mampu memasarkan produknya ke semua wilayah mulai dari dalam negeri sampai keluar negeri, bahkan sampai saat ini produk CV. Adeeva Group sudah masuk kepelosok desa.

Pada awalnya karyawan yang bekerja di CV. Adeeva Group merupakan teman terdekat ibu Ana Mahnan, serta tetangga di sekitarnya yang tidak mampu dalam bidang perekonomiannya. Karena niat awal ibu Ana Mahnan mendirikan CV. Adeeva Group adalah untuk meringankan beban perekonomian masyarakat di sekitarnya. Salah satunya dengan mengurangi angka pengangguran yang ada, mulai dari temen-teman alumni untuk bergabung dalam bekerja sama dalam mengelola CV. Adeeva Group sampai mengajak para ibu-ibu yang tidak memiliki pekerjaan untuk bekerja di perusahaannya.

Seiring berjalannya waktu CV. Adeeva Group mengalami perkembangan yang sangat pesat. Hal ini dilandasi dengan semakin bertambah karyawan yang bekerja di CV. Adeeva Group, yang pada awalnya hanya terdiri dari 2 karyawan saja. Namun semakin bertambahnya volume penjualan serta permintaan pasar yang semakin meningkat maka penambahan karyawan menjadi suatu hal yang harus segera dipenuhi. Hingga saat ini karyawan CV. Adeeva Group berjumlah 60 orang karyawan sesuai dengan SOP perusahaan. Mengingat SDM merupakan hal yang sangat urgent dalam menentukan keberhasilan dan kesuksesan sebuah perusahaan, maka CV. Adeeva Group melakukan inovasi-inovasi dan strategistrategi dalam pengelolaan SDM. Sehingga mampu menguatkan etos kerja agar CV. Adeeva Group mampu bersaing dengan perusahaan lain serta bisa memiliki pangsa pasar yang cukup signifikan dengan tetap mengindahkan etika bisnis Islam.

Selain itu CV. Adeeva Group juga menerapkan reward dan punish bagi karyawan, stokest dan reseller dalam pekerjaannya, sehingga baik karyawan maupun stokest dan reseller yang taat peraturan serta bisa memenuhi target akan mendapat reward semisal kalung emas, gelang emas dan lain-lain. Tidak hanya reward, punish pun juga tetap berlaku, sehingga baik karyawan ataupun stokest dan reseller yang tidak mentaati peraturan akan mendapatkan punishment. Hal ini 
bertujuan untuk memompa semangat kerja karyawan serta untuk menanamkan keinginan untuk selalu berlomba-lomba dalam melakukan kebaikan.

Namun melihat banyaknya fakta perusahaan atau pelaku bisnis yang tidak memperhatikan etika berbisnis dalam Islam. Terlebih lagi dari jaman yang moderen saat ini kebanyakan perusahan atau pelaku bisnis jarang memperhatikan sistem manajemen yang Islami serta kurangnya memamfaatkan sumber daya manusia yang Islami dikarenakan pengetahuan masyarakat pengguna belum secepat pertumbuhan usahanya. Demikian pula kurangnya ketersediaan sumber daya manusia yang berkualitas sesuai kualisifikasi yang dibutuhkan. Sehingga tujuan yang ingin di capai dalam kajian ini adalah untuk mendeskripsikan strategi manajemen sumber daya manusia islami dalam meningkatkan kinerja karyawan di CV. Adeeva Group Besuk Wirowongso Jember.

\section{KAJIAN TEORI}

\section{Strategi Sumber Daya Manusia Islami}

Strategi yang dilakukan Nabi Muhammad SAW. Meliputi Perencanaan yang menarik sumber daya yang berkualitas. ${ }^{9}$ Perencanaan sumber daya manusia yang dilakukan Nabi Muhammad SAW. Mengacu pada al-Qur'an untuk menjadikan orang berlaku adil, Allah SWT. Memerintahkan berbuat adil dalam melaksanakan isi al-Qur'an yang menjelaskan segala aspek kehidupan manusia, serta berbuat ihsan (keutamaan). Adil berarti mewujudkan kesamaan dan keseimbangan diantara hak dan kewajiban mereka. Hak asasi mereka tidaklah boleh dikurangi disebabkan adanya kewajiban atas mereka. Kezaliman lawan dari keadilan dan wajib dijauhi. Hak setiap orang harus diberikan sebagaimana mestinya. Kebahagiaan barulah dirasakan oleh manusia bilamana hak-hak mereka dijamin dalam masyarakat, hak setiap orang dihargai, dan golongan yang kuat mengayomi yang lemah. Penyimpangan dari keadilan penyimpangan dari Allah SWT.

Allah SWT. Menetapkan keadilan sebagai dasar umum bagi kehidupan masyarakat bagi setiap bangsa dan masa, untuk setiap ummat pada segala zaman. Keadilan merupakan tujuan dan merupakan pengutusan Rasul- rasul ke dunia dan

\footnotetext{
${ }^{9}$ Veithzal Rivai, Dkk. Islamic Business and Eonomic Ethics (Jakarta: Bumi Aksara,2012), 301. Cet,Ke-1
} 
tujuan dari syariat dan hukum yang diturunkan bersama mereka. Seperti dalam firman Allah SWT dalam Q.S. Al-Hadid ayat: 25 yang artinya:

"Sesungguhnya kami telah mengutus Rasul-rasul kami dengan membawa bukti-bukti yang nyata dan telah kami turunkan bersama mereka Al-kitab dari neraca (keadilan) supaya manusia dapat melaksanakan keadilan. Dan kami ciptakan besi yang padanya terdapat kekuatan yang hebat dan berbagai mamfaat bagi manusia, (supaya mereka mempergunakan besi itu) dan supaya Allah mengetahui siapa yang menolong (agama)-Nya dan rasul-rasulnya padahal Allah tidak melihatnya. Sesungguhnya Allah maha kuat lagi maha perkasa ${ }^{10}$.

Adapun macam-macam keadilan yang dikemukakan oleh Islam sebagai berikut.

a. Keadilan dalam kepercayaan

Menurut al-Qur'an kepercayaan syirik itu suatu kezaliman sebagaimana Firman Allah SWT dalam Q.S. Luqman ayat:13 yang artinya: “Janganlah kamu mempersekutukan Allah, sesungguhnya mempersekutukan (Allah) adalah benar-benar kezaliman yang besar. ${ }^{11}$

b. Keadilan dalam rumah tangga.

Dari rumah tangga yang baik, lahir individu-individu anak yang baik pula karena demikian itu, Islam menetapkan peraturan-peraturan dalam pembinaan rumah tangga yang cukup luas dan sempurna. Bilamana rumah tangga sejahtera, Negara akan kuat.

c. Keadilan dalam perjanjian.

Dalam kehidupan orang-orang ataupun suatu bangsa, pastilah mereka memerlukan bantuan orang lain. Tolong menolong, bantu-membantu sesama manusia dalam usaha pencapaian kebutuhan masing-masing merupakan ciri kehidupan kemanusiaan Agama Islam memberikan tuntunan dalam menyelenggarakan hidup tolong-menolong itu. Umpama dalam soal muamalah, 2008),541.

10 Departemen Agama RI, AL-Qur'an dan Terjemahanya (Semarang: Karya Utama, ${ }^{11}$ Ibid, 412. 
seperti utang piutang, jual beli, sewa-menyewa dan sebagainya, dengan suatu perjanjian. $^{12}$

d. Keadilan dalam hukum

Dalam Islam semua manusia sama dihadapan Allah, tidak ada perbedaan orang kulit putih dan orang kulit hitam, antara anak raja dengan anak rakyat, semua sama dalam perlakuan hukum. Melaksanakan keadilan hukum dipandang oleh Islam sebagai melaksanakan amanat,

Demikian beberapa macam keadilan yang ditulis dan jelas diperintahkan oleh Islam. Di samping berbuat keadilan, Allah SWT. Memerintahkan pula ihsan yang berarti keutamaan seperti membalas kebaikan orang lain dengan kebaikan yang lebih baik atau memaafkan orang lain.

\section{Manajemen Sumber Daya Manusia Islami}

Manajemen sumber daya manusia (SDM) merupakan sebuah bagian dari manajemen. Oleh sebab itu, teori yang ada dalam manajemen umum menjadi pokok pembahasannya. Manajemen Sumber Daya Manusia lebih memfokuskan pembahasan terkait dengan pengaturan peranan manusia dalam rangka mewujudkan tujuan yang optimal. ${ }^{13}$

1. Pelatihan dan Pengembangan

Pelatihan adalah proses melatih karyawan baru atau karyawan yang akan memperoleh penempatan baru dengan keterampilan dasar yang diperlukannya untuk melakukan pekerjaan. Tujuan dari kajian ini adalah agar tenaga kerja dapat mencapai suatu standar, baik dalam keterampilan, pengetahuan maupun dalam tingkah laku. Fokus dari pelatihan yaitu pada pekerjaan sekarang. Sedangkan pengembangan lebih diarahkan untuk yang sifatnya jangka panjang dan bertujuan untuk mengembangkan kemampuan karyawan untuk tugas-tugas mendatang. Tujuan pelatihan dan pengembangan adalah untuk pembentukan karakter yang Islami dengan mengacu pada shidiq, amanah, fathanah, dan

\footnotetext{
12 Veithzal Rivai, Dkk. Islamic Business and Economic Ethics, 305.

${ }^{13}$ Julita Prisca Aulia "Penerapan Manajemen SDM Dalam Peningkatan Kinerja Karyawan Pada Bank BRI Syariah KCP Magelang Perspektif Islam" (Skrips - Ilmu Agama Islam Universitas
} Islam Indonesia,2017), 32. 
tabligh, sedangkan yang menjadi tujuan dalam pelatihan konvensional hanyalah keterampilan pekerja.

Islam sangat mendorong untuk melakukan pelatihan dan pengembangan terhadap para tenaga kerjanya dengan tujuan mengembangkan kompetensi dan kemampuan teknis pegawai dalam menunaikan tanggungjawab pekerjaannya. ${ }^{14}$

2. Kompensasi

Kompensasi merupakan sesuatu yang diberikan kepada tenaga kerja sebagai tukaran atas kontribusinya kepada perusahaan. Dalam Islam, kompensasi atau kesejahteraan mendapat perhatian yang besar. Kompensasi dapat bersifat material dan non material, kompensasi material seperti dalam bentuk uang atau barang, sedangkan kompensasi non material seperti pujian, kecepatan dalam memberikan uang/barang tersebut, penghormatan, dan sebagainya $^{15}$

\section{Kinerja Karyawan Islami}

Kinerja adalah suatu proses yang dirancang untuk meningkatkan kinerja organisasi, kelompok dan individu yang digerakkan oleh para manajer. Pada dasarnya kinerja adalah suatu proses yang di laksanakan secara sinergi antara manajer, individu dan kelompok terhadap suatu pekerjaan di dalam organisasi. Kinerja didasarkan pada kesepakatan tentang sasaran, persyaratan pengetahuan, keahlian, kompetensi, rencana kerja dan pengembangan. Dengan demikian, kinerja mencakup pengkajian ulang terhadap kinerja secara berkesinambungan dan dilakukan secara bersama berdasarkan kesepakatan mengenai sasaran, persyaratan pengetahuan, keahlian, kompetensi, rencana kerja peningkatan dan pengembangan lebih lanjut.

Kinerja adalah hasil yang diperoleh suatu organisasi baik organisasi tersebut bersifat profit oriented dan non profit oriented yang dihasilkan selama satu periode waktu. Kinerja adalah gambaran mengenai suatu kegiatan / program / kebijaksanaan

\footnotetext{
${ }^{14}$ Ahmad Ibrahim Abu Sinn, Manajemen Syariah Sebuah Kajian Historis dan Temporer, (Jakarta: Raja Grafindo Persada, 2008), 117

${ }^{15}$ Wibowo, Manajemen Kinerja,( Jakarta: Rajawali pers, 2013,), 348.
} 
dalam mewujudkan sasaran, tujuan, misi dan visi organisasi yang tertuang dalam perusahaan skema strategis suatu organisasi. ${ }^{16}$

Kinerja adalah hasil dari pekerjaan organisasi yang di kerjakan oleh karyawan dengan sebaik-baiknya sesuai dengan petunjuk (manual), arahan yang diberikan oleh pimpinan (manajer), kompetensi dan kemampuan karyawan mengembangkan nilainya dalam bekerja. ${ }^{17}$

Kinerja karyawan adalah hasil pekerjaan yang dicapai seseorang berdasarkan persyaratan-persyaratan pekerjaan (job requirement). Suatu pekerjaan mempunyai persyaratan tertentu untuk dapat dilakukan dalam mencapai tujuan yang disebut juga sebagai standar pekerjaan (job standar).

Standar kinerja adalah tingkat yang diharapkan suatu pekerjaan tertentu untuk dapat diselesaikan, dan merupakan pembanding atas tujuan atau target yang ingin dicapai. Hasil pekerjaan merupakan hasil yang diperoleh seorang karyawan dalam mengerjakan pekerjaan sesuai persyaratan pekerjaan atau standar kinerja.

Kinerja adalah proses yang dilakukan organisasi untuk mengevaluasi atau menilai keberhasilan karyawan dalam melaksanakan tugasnya. Kinerja dapat ditinjau ke dalam jumlah dan kualitas pekerjaan yang diselesaikan pada periode tertentu. Kinerja seorang karyawan dapat dinilai berdasarkan jumlah pekerjaan yang diselesaikan dalam batas waktu tertentu. Karyawan yang dapat menyelasaikan pekerjaan dalam jumlah yang melampaui standar pekerjaan dinilai dengan kinerja yang baik. ${ }^{18}$

Karyawan adalah sumber daya manusia atau penduduk yang bekerja di suatu institusi baik pemerintah maupun swasta (bisnis). Adapun beberapa rumusan mengenai karyawan dan pentingnya dalam suatu institusi. ${ }^{19}$

\section{Faktor-Faktor yang Mempengaruhi Kinerja}

${ }^{16}$ Irham Fahmi, Manajemen Kinerja Teori dan Aplikasi (Bandung: Alfabeta, 2011), 2.

${ }^{17}$ M. Ma'ruf Abdullah, Manajemen Bisnis Syariah (Yogjakarta: ASWAJA, 2013), 331.

${ }^{18}$ Wilson Bangun, Manajemen Sumber Daya Manusia (Jakarta: Penerbit Erlangga, 2012), 231-232.

${ }^{19}$ Ma'aruf Abdullah, Manajemen dan Evaluasi Kinerja Karyawan (Yogjakarta: Aswaja Pressindo, 2014), 6. 
Faktor yang mempengaruhi kinerja pencapaian kinerja adalah faktor kemampuan dan faktor motivasi. Hal ini sesuai dengan pendapat Ketih Davis 
yang dikutip oleh Anwar dalam bukunya yang berjudul Manajemen Sumber Daya Manusia Perusahaan yang merumuskan bahwa:

$$
\begin{array}{ll}
\text { Human performance } & =\text { Ability }+ \text { Motivation } \\
\text { Motivation } & =\text { Attitude }+ \text { Situation } \\
\text { Ability } & =\text { Knowladge }+ \text { Skill }
\end{array}
$$

1. Faktor Kemampuan

Secara psikologis, kemampuan pegawai terdiri dari kemampuan potensi (IQ) dan kemampuan realitas (pengetahuan + keterampilan). Artinya pengawai yang memiliki IQ di atas rata-rata dengan pendidikan yang memadai untuk jabatannya dan terampil dalam mengerjakan pekerjaan sehari-hari, oleh karena itu akan lebih mudah mencapai kinerja yang diharapkan. Oleh karena itu pengawai perlu ditempatkan pada pekerjaan yang sesuai dengan keahliannya. Maksudnya adalah pengetahuan tentang pekerjaan. Seseorang yang memiliki pengetahuan tentang pekerjaan secara baik akan memberikan hasil pekerjaan yang baik, demikian pula sebaliknya. Artinya dengan mengetahui pengetahuan tentang pekerjaan akan memudahkan untuk melakukan pekerjaannya.

2. Faktor Motivasi

Motivasi berbentuk dari sikap seorang pengawai yang dalam menghadapi situasi kerja. Motivasi merupakan kondisi yang menggerakkan dari pengawai yang terarah untuk mencapai tujuan organisasi (tujuan kinerja). ${ }^{20}$

3. Faktor Rancangan Kerja

Merupakan rancangan pekerjaan yang akan memudahkan karyawan dalam mencapai tujuannya. Artinya jika suatu pekerjaan memiliki rancangan yang baik, maka akan memudahkan untuk menjalankan pekerjaan tersebut secara tepat dan benar. Dengan demikian rancangan akan mampu meningkatkan kinerja karyawannya.

4. Faktor Kepribadian

\footnotetext{
${ }^{20}$ Anwar Prabu Mangkunegara, Manajemen Sumber Daya Manusia Perusahaan, (Bandung: Remaja Rosdakarya, 2009), 67.
} 
Kepribadian seseorang atau karakter yang dimiliki seseorang. Setiap orang memiliki kepribadian atau karakter yang berbeda satu sama lainnya. Seseorang yang memiliki kepribadian atau karakter yang baik, akan dapat melakukan pekerjaan secara sungguh-sungguh penuh tanggung jawab sehingga hasil pekerjaannya juga baik.

\section{Faktor Disiplin Kerja}

Merupakan usaha karyawan untuk menjalankan aktivitas kerjanya secara sungguh-sungguh. Disiplin kerja dalam hal ini dapat berupa waktu, misalnya masuk kerja selalu tepat waktu. Kemudian disiplin dalam mengerjakan apa yang diperintahkan kepadanya sesuai dengan perintah yang harus dikerjakan. Karyawan yang disiplin akan mempengaruhi kinerja.

\section{Penilaian Kinerja}

Penilaian kinerja pengawai dikenal dengan istilah "performance rating, performance appraisal, personnel assessment, employe evaluation, merit rating, effeciency rating, service rating" untuk mempermudah seabagai terjemahan dalam bahasa Indonesia dipakai istilah "penilaian kinerja". Penilaian kinerja merupakan salah satu rangkaian fungsi manajemen sumber daya manusia. Setelah karyawan diterima menjadi calon pegawai, ada yang langsung bekerja atau masuk ke pelatihan terlebih dulu. Selama bekerja karyawan tersebut akan dinilai perilaku dan hasil kerjanya atau dengan kata lain kinerjanya.

Penilaian kinerja penting artinya bukan hanya untuk kepentingan perusahaan semata, akan tetapi juga untuk kepantingan karyawan itu sendiri. Bagi perusahaan, penilaian kinerja karyawan secara keseluruhan dapat dilihat dari jumlah laba yang akan diperolehnya dalam suatu periode. Sedangkan bagi karyawan, kegunaan penilaian kinerja adalah untuk mengukur kemampuannya dalam melakukan suatu pekerjaan, sekaligus sebagai koreksi atas hasil pekerjaannya. ${ }^{21}$ Penilaian pekerjaan adalah mengenai pekerjaan dan tugas, bukan mengenai orang. Akan tetapi, penilaian karyawan adalah mengenai kecakapan dan prestasi para pemegang jabatan, untuk membedakannya dari penilaian tingkattingkat penilaian

${ }^{21}$ Kasmir, Manajemen Sumber Daya Manusia (Teori Dan Praktik), (Jakarta: Rajawali Pers, 2016), 179-180. 
pekerjaan. Penilaian pekerjaan menentukan kedudukan nisbi pekerjaan-pekerjaan dalam suatu organisasi. Penilaian pekerjaan maupun penilaian kinerja adalah alatalat yang dapat digunakan bersama-sama untuk menentukan upah yang adil berdasarkan baik tingkat pekerjaan maupun tingkat prestasi. ${ }^{22}$

Penilaian prestasi pegawai adalah suatu proses prestasi kerja pegawai yang dilakukan pemimpin perusahaan secara sistematik berdasarkan pekerjaan yang ditugaskan kepadanya. Penilaian pegawai adalah suatu penilaian secara sistematis kepada pegawai oleh beberapa orang ahli untuk suatu atau tujuan tertentu. Ada beberapa metode penelitian terhadap pegawai. ${ }^{23}$ Metode mana yang harus dianut tergantung pada kondisi dan situasi suatu perusahaan. Metode penilaian yang akan dianut tergantung pula terhadap tersedianya tenaga penilaian yang telah berpengalaman.

\section{HASIL DAN PEMBAHASAN}

Berdasarkan hasil temuan lapangan, dapat dianalisa bahwa Strategi manajemen sumber daya manusia Islami dalam meningkatkan etos kerja di CV Adeeva Group Besuk Wirwongso Jember terdiri dari keputusan-keputusan yang harus diambil. Strategi manajemen sumber daya manusia Islami yang diterapkan di CV Adeeva Group ialah menetapkan keadilan. Sebagaimana keadilan yang diterapkan di CV Adeeva Group sudah sepenuhnya dikatakan adil. Karena adil dalam hal ini seperti adanya reward bagi mereka yang memang paling teladan serta dapat bonus uang bagi mereka yang taat peraturan. Jadi mereka yang memang benar pantas dan etos kerjanya bagus maka dia yang berhak mendapatkan, sedangkan bagi yang melanggar peraturan maka gaji akan dipotong $50 \%$.

Menurut teori, adil berarti mewujudkan kesamaan dan keseimbangan diantara hak dan kewajiban mereka. ${ }^{24}$ Melihat fakta di lapangan serta teori yang ada bahwa terdapat kesesuaian antara fakta yang ada di CV Adeeva Group ini dilihat

${ }^{22}$ Lijan Poltak Sinambela, Manajemen Sumber Daya Manusia, (Jakarta: PT Bumi Aksara, 2016), 515

${ }^{23}$ M. Manullang Dan Marithot Manullang, Manajemen Personalia, (Yogjakarta: Gajah Mada University Press, 2011), 136. 301. Cet,Ke-1

${ }^{24}$ Veithzal Rivai, Dkk. Islamic business and economic ethics, (Jakarta: Bumi Aksara,2012), 
dari pemberian reward sesuai dengan peraturan dan porsinya masingmasing jadi sesuai tidak ada perbedaan.

\section{Pelatihan dan Pengembangan}

CV Adeeva Group dalam melakukan pelatihan dan pengembangan dengan menyediakan buku-buku bisnis dan video-video tutorial agar dapat dipelajari serta memberikan pelatihan-pelatihan dan menyediakan sekolah online karyawan sesuai dengan kebutuhan serta dibekali berbagai macam ilmu marketing. Yang dapat memacu keberhasilan seluruh anggota untuk sukses secara berjama'ah. Secara berkala, pemilik, memberikan training, secara cuma-cuma tanpa dipungut biaya sepeserpun kepada agen dan stokis, serta mendatangkan trainer-trainer undangan yang ahli dibidangnya untuk memberikan ilmu kepada kelurga besar Adeeva Group.

\section{Kompensasi}

CV Adeeva Group dalam memberikan konpensasi dan bonus seperti adanya bonus atau tunjangan sosial seperti BPJS bagi para stakeholder serta THR bagi masyarakat sekitar. Selain itu juga perusahaan mengeluarkan sedekah bagi orang yang membutuhkanya. CV Adeeva Group dalam menerapkan pembagian bonus bagi para karyawan yang taat peraturan dan tidak pernah melakukan kesalahan sedangkan bagian admin mendapatkan reward, bahkan admin yang paling teladan itu bisa dibawa umroh bareng dengan agen dan stokis.

\section{Faktor Disiplin Kerja}

Disiplin kerja dalam hal ini dapat berupa waktu, misalnya masuk kerja selalu tepat waktu. Kemudian disiplin dalam mengerjakan apa yang diperintahkan kepadanya sesuai dengan perintah yang harus dikerjakan. Karyawan yang disiplin akan mempengaruhi kinerja. Adapun jika dilihat dari karyawan yang ada di CV Adeeva Group yang sudah diberikan tanggung jawab oleh perushaan mereka semua sudah sangat disiplin, semangat dan tanggung jawab atas pekerjaan yang telah diberikan dan professional.

\section{SIMPULAN}

Strategi manajemen SDM Islami dalam meningkatkan kinerja karyawan di CV Adeeva Group Besuk Wirowongso Jember dapat meningkatkan kinerja 
karyawannya yang baik dengan adanya keadilan, pelatihan dan pengembangan, kompensasi serta disiplin kerja hal ini dapat berpengaruh terhadap peningkatan kinerja karyawan di CV Adeeva Group Besuk Wirowongso Jember.

Strategi pengembangan sumber daya manusia Islami di CV Adeeva Group Besuk Wirowongso Jember sudah sesuai dengan yang dilakukan oleh Nabi Muhammad SAW meliputi, merencanakan dan menarik sumber daya manusia yang berkualitas, menilai kinerja sumber daya manusia, memberikan motivasi dan memelihara sumber daya manusia yang berkualitas. Karena perencana sumber daya manusia Islami yang dilakukan Nabi Muhammad Saw mengacu pada alQur'an untuk menjadikan orang berlaku adil, berbuat kebajikan, memberi bantuan, melarang kemungkaran, kekejian dan permusuhan.

\section{Daftar Pustaka}

Abdullah, M. Ma'ruf. Manajemen Bisnis Syariah. Yogjakarta: ASWAJA, 2013. . Manajemen dan Evaluasi Kinerja Karyawan. Yogjakarta: Aswaja Pressindo, 2014.

Alma, Buchari dan Doni. Manajemen Bisnis Syari'ah. Bandung: Penerbit Alfabeta, 2014.

Aulia, Julita Prisca. Penerapan Manajemen SDM dalam Peningkatan Kinerja Karyawan Pada Bank BRI Syariah KCP Magelang Perspektif Islam. Skrips - Ilmu Agama Islam Universitas Islam Indonesia, 2017.

Bangun, Wilson. Manajemen Sumber Daya Manusia. Jakarta: Penerbit Erlangga, 2012.

Departemen Agama RI. Al-Qur'an dan Terjemahanya. Semarang: Karya utama, 2008.

Fahmi, Irham. Manajemen Kinerja Teori dan Aplikasi. Bandung: Alfabeta, 2011.

Hasibun, Malayu SP. Manajemen Sumber Daya Manusia Dasar dan Kunci Keberhasilan. Jakarta: Haji Masagung, 1994.

Istijanto. Riset Sumber Daya Manusia. Jakarta: PT Gramedia Pustaka Utama, 2005.

Kasmir. Manajemen Sumber Daya Manusia (Teori Dan Praktik). Jakarta:

Rajawali Pers, 2016.

Mangkunegara, Anwar Prabu. Manajemen Sumber Daya Manusia Perusahaan. Bandung: Remaja Rosdakarya, 2009.

Manullang, M. dan Marithot Manullang. Manajemen Personalia. Yogjakarta: Gajah Mada University Press, 2011. 
Rivai, Veithzal dan Muhammad Syafii Antonio dkk. Islamic Business Management. Yogyakarta: BPF cet. ke-2, 2017. 2012. dkk. Islamic Business and Economic Ethics. Jakarta: Bumi Aksara,

Sinambela, Lijan Poltak. Manajemen Sumber Daya Manusia. Jakarta: PT Bumi Aksara, 2016.

Sinn, Ahmad Ibrahim Abu. Manajemen Syariah Sebuah Kajian Historis dan Temporer. Jakarta: Raja Grafindo Persada, 2008.

Tasmara, Toto. Etos Kerja Pribadi Mulia. Yogyakarta: PT Dana Bhati Wakaf, 1995.

Wibowo. Manajemen Kinerja. Jakarta: Rajawali Pers, 2013.

Yusanto, Muhammad Imail dan Muhammad Charabet Widjajakusuma. Menggaagas Bisnis Islam. Jakarta: Gema Insani, 2002. 